\title{
Modeling the Fenton depuration of the effluent from a slaughterhouse based on design of experiments
}

\begin{abstract}
In an effort to improve the quality of treated water, the implementation of a new technology referred to as Advanced Oxidation Processes (AOP) is being examined, either alone or in combination with other processes. When working with real conditions there are sometimes changes which involve adjustments of the process, and it is easier to perform such adjustments when it has a reliable mathematical model. The studied scaled design referred to as Fenton treatment, involving the use of a central-composite design (quadratic model) which was tested on the effluent discharge of a slaughterhouse. As a result of our treatability study, we experienced removal efficiencies based on chemical oxygen demand (COD) greater than $85 \%$, while ascertaining that removal process was the result of chemical oxidation and coagulation.
\end{abstract}

Keywords: central composite design, coagulation, chemical oxidation, fenton reaction, model, slaughterhouse effluent
Volume 2 Issue 2 - 2017

\author{
Javier Páramo-Vargas,' 'Manuel I Maldonado- \\ Rubio, ${ }^{2}$ Fernando ${ }^{1}$ Gómez-Castro, ${ }^{3}$ Juan M \\ Peralta-Hernández ${ }^{4}$ \\ 'Departamento de Ingeniería Ambiental Universidad Tecnológica, \\ Universidad Tecnológica de Léon, Mexico \\ 2Plataforma Solar de Almería-CIEMAT, Spain \\ ${ }^{3}$ Departamento de Ingeniería Química, Universidad de \\ Guanajuato, Mexico \\ ${ }^{4}$ Departamento de Química, Universidad de Guanajuato, Mexico
}

Correspondence: Juan M Peralta-Hernández, Universidad de Guanajuato, DCNE, Departamento de Química, Cerro de la Venada S/N, Pueblito de Rocha, Guanajuato, Gto. CP. 36040, Mexico,

Email jparamo@utleon.edu.mx, juan.peralta@ugto.mx

Received: February 08, 2017 | Published: April 06, 2017

\section{Introduction}

The meat processing industry generates large quantities of waste water with high content of organic matter, which must be removed prior to being discharged. ${ }^{1,2}$ In order to improve water quality and ensure regulatory compliance, Advanced Oxidation Processes (AOP) may be used in combination with other processes as pre or post treatment. It has been reported that Fenton process have removal efficiencies of chemical oxygen demand (COD) greater than $85 \%{ }^{3,4}$ In this work, we have used AOPs based on Fenton process in the depuration of the effluent of a slaughterhouse; in order to improve its quality. Fenton process is based on the oxidative action of free hydroxyl radicals, with a redox potential of $2.8 \mathrm{~V}^{5}$ produced by Fenton reaction in acid medium. This reaction must not be analyzed alone, because there are others occurring simultaneously, with different reaction constants, so Eq. 1 to 7 are the principal ones. ${ }^{6,7}$

$$
\begin{gathered}
\mathrm{Fe}^{2+}+\mathrm{H}_{2} \mathrm{O}_{2} \rightarrow \mathrm{Fe}^{3+}+{ }^{\bullet} \mathrm{OH}+\mathrm{OH}^{-} \mathrm{K}_{1}=70 \\
\bullet \mathrm{OH}+\text { organic matter } \rightarrow \text { final products }
\end{gathered}
$$

$$
\begin{array}{ll}
\bullet \mathrm{OH}+\mathrm{H}_{2} \mathrm{O}_{2} \rightarrow \mathrm{H}_{2} \mathrm{O}+\mathrm{HO}_{2}^{\bullet} & \mathrm{K}_{3}=3.3 \times 10^{7} \mathrm{M}^{-1} \mathrm{~s}^{-1} \\
\mathrm{Fe}^{3+}+\mathrm{H}_{2} \mathrm{O}_{2} \rightarrow \mathrm{Fe}^{2+}+\mathrm{HO}_{2}+\mathrm{H}^{+} & \mathrm{K}_{4}=0.01 \mathrm{M}^{-1} \mathrm{~s}^{-1} \\
\mathrm{Fe}^{3+}+\mathrm{HO}_{2} \cdot \rightarrow \mathrm{Fe}^{2+}+\mathrm{O}_{2}+\mathrm{H}^{+} & \mathrm{K}_{5}=1.2 \times 10^{6} \mathrm{M}^{-1} \mathrm{~s}^{-1} \\
\mathrm{Fe}^{2+}+\mathrm{HO}_{2} \cdot \mathrm{Fe}^{3+}+\mathrm{HO}^{-} & \mathrm{K}_{6}=1.3 \times 10^{6} \mathrm{M}^{-1} \mathrm{~s}^{-1}
\end{array}
$$

$$
\cdot \mathrm{OH}+\mathrm{Fe}^{2+} \rightarrow \mathrm{Fe}^{3+}+\mathrm{OH}^{-}
$$

$$
\mathrm{K}_{7}=3.2 \times 10^{8} \mathrm{M}^{-1} \mathrm{~s}^{-1}
$$

When applying this treatment with real wastewaters, sometimes there are changes in its quality and is convenient to have a mathematical model which allows to predict which adjustments are necessary. ${ }^{6,8}$ There are models based on chemical analysis and experimental determination of some parameters ${ }^{6}$ but it was decided to work on the development of a statistical model using the software Statgraphics; due to the quantity of substances present in our sampled real effluent and the high number of experimental data available. Taking this in consideration we developed a model for the Fenton treatment of the effluent of a slaughterhouse, with inclusion of the following factors: initial ferrous ion concentration $\left(\mathrm{Fe}^{2+}\right)_{0}$, initial hydrogen peroxide concentration $\left(\mathrm{H}_{2} \mathrm{O}_{2}\right)_{0}$, initial chemical oxygen demand $(\mathrm{COD})_{0}$ and time $(\mathrm{t})$. Based on our analysis, we conducted a kinetic study as a complement.

\section{Materials and methods}

\section{Materials}

As it has been commented the water quality was a variable throughout this study; this quality is represented by COD, so periodically samples of the effluent were taken at different times at the distal end of the actual wastewater treatment facility (plant), in order to obtain working samples with unique qualities, storing them at $4^{\circ} \mathrm{C}$. Some of the working samples were prepared by dilution. For the objective of the study we focused on the COD parameter, of which highest value was $577 \mathrm{mg} \mathrm{L}^{-1}$, and flow with an average value of $350 \mathrm{~m}^{3} \mathrm{~d}^{-1}$. In this analysis, we employed ferrous sulphate 
$\left(\mathrm{FeSO}_{4} \cdot 7 \mathrm{H}_{2} \mathrm{O}\right.$, provided by $\left.\mathrm{KEM}\right)$, titanium oxysulphate $\left(\mathrm{O}_{5} \mathrm{STi}\right.$ $\mathrm{xH}_{2} \mathrm{SO}_{4}$, provided by FLUKA Analytical), $\mathrm{H}_{2} \mathrm{O}_{2}$ (provided by KEM), sulfuric acid, orthophenanthroline and ferrous ammonium sulphate, all chemicals used is analytical grade and purchased from Karal and KEM. In preparing solutions pure water (it is better if we mention type of water like type-II or type-III) was used (conductivity $<1 \mu \mathrm{Scm}^{-1}$ ) from a Millipore equipment model Elix 5.

\section{Equipment}

During tests conductivity, $\mathrm{pH}$ and temperature were monitored using a HACH Sension156 portable multiparameter. For chemical oxygen demand determination, a reactor HI839800 from Hanna Instruments was used and finally, colorimetric measurements were conducted using an UV spectrophotometer Evolution 300UVVis (Thermo Scientific). The tests were carried out using a batch reactor of $1 \mathrm{~L}$, with agitation of $350 \mathrm{rpm}$ at $23^{\circ} \mathrm{C}$, this set up has been reported elsewhere. ${ }^{9}$ In experiment conductivity, $\mathrm{pH}$ and temperature were monitored using $\mathrm{HACH}$ Sension 156 portable multiparameter. Chemical oxygen demand (COD) were analyzed on HI839800 COD reactor (Hanna instrument)

\section{Analytical methods}

As it has been mentioned, COD was established as the principal monitoring parameter, with two kinds of COD; the total chemical oxygen demand $\left(\mathrm{COD}_{t}\right)$ and the dissolved chemical oxygen demand $\left(\mathrm{COD}_{\mathrm{d}}\right)$. Taking this into account, each sample was divided into two parts, one taken from the mixed sample, for $\mathrm{COD}_{t}$ and another by filtering through a fiberglass filter Whatman $\mathrm{A}$, for $\mathrm{COD}_{\mathrm{d}}$. COD measurements were in accordance with the Standard Methods. ${ }^{10}$ Monitoring of $\mathrm{Fe}^{2+}$ was implemented using the phenanthroline method ${ }^{10}$ measuring the absorbance of its orange-red complex with phenanthroline at a wavelength $(\lambda)$ of $508 \mathrm{~nm}$. The measurement of $\mathrm{Fe}_{\mathrm{t}}$ involved reduction of $\mathrm{Fe}^{3+}$ to $\mathrm{Fe}^{2+}$ by using ascorbic acid before the UV-spectrophotometry, and at the end $\mathrm{Fe}^{3+}$ was the difference between it and $\mathrm{Fe}^{2+}$. On the other hand, the measurement of the $\mathrm{H}_{2} \mathrm{O}_{2}$ was also completed by UV-spectrophotometry at a $\lambda$ of $406 \mathrm{~nm} .{ }^{11}$

\section{Design of experiments}

Basically, we were focused on the development of a viable model. Target response was established as the removal efficiency of COD (RE), which was calculated through Eq. 8.

$$
R E_{t}=\frac{C O D_{o}-C O D_{d}}{C O D_{o}} * 100 \%
$$

The effects of principal factors: $\left(\mathrm{Fe}^{2+}\right)_{0},\left(\mathrm{H}_{2} \mathrm{O}_{2}\right)_{0}, \mathrm{COD}_{\mathrm{t}}$ and time, were studied using a Central Composite Design (CCD) $2^{4}$, with response surface methodology (RSM), involving a total of 52 tests; 16 factorial points, 8 axial points and 2 central points; each one with two replicates and whose design information is presented in Table 1. Once obtained the model, was validated by applying to a couple of real samples.
Table I Each one with two replicates and whose design information

\begin{tabular}{llllll}
\hline \multirow{2}{*}{ Factor } & \multicolumn{6}{l}{ Factor levels } & & \\
\cline { 2 - 6 } & $\boldsymbol{- \alpha}$ & $\mathbf{- 1}$ & $\mathbf{0}$ & $\mathbf{1}$ & $+\boldsymbol{\alpha}$ \\
\hline$\left(\mathrm{Fe}^{2+}\right)_{0}\left(\mathrm{mg} \mathrm{L}^{-1}\right)$ & 13.9 & 27.9 & 41.9 & 55.8 & 69.8 \\
$\left(\mathrm{H}_{2} \mathrm{O}_{2}\right)_{0}\left(\mathrm{mg} \mathrm{L}^{-1}\right)$ & 100 & 200 & 300 & 400 & 500 \\
$\mathrm{COD}_{\mathrm{t}}\left(\mathrm{mg} \mathrm{L}^{-1}\right)$ & 265.1 & 355 & 435.5 & 503 & 583.8 \\
time $(\mathrm{min})$ & 2.5 & 5 & 7.5 & 10 & 12.5
\end{tabular}

\section{Results and discussion}

Applying the ANOVA analysis, it was found for the quadratic model, the statistic $\mathrm{R}^{2}$ of 80.5059 and $\mathrm{R}_{\text {adjusted }}$ of 73.1298 , and that the four factors studied were significant. Figure 1(A) depicts the behavior of principal factors, showing that by increasing each one, RE increases, having different levels of influence in the following order of magnitude: $\left(\mathrm{Fe}^{2+}\right)_{0}>$ time $>\mathrm{COD}_{\mathrm{t}}>\left(\mathrm{H}_{2} \mathrm{O}_{2}\right)_{0}$. On the other hand Figure 1(B) depicts the response surface for the optimal removal condition of $\mathrm{COD}$ for one of the effluents studied $\left(\mathrm{COD}_{0}\right.$ of $\left.503 \mathrm{mgL}^{-1}\right)$ at $10 \mathrm{~min}$, corresponding to a true sample, not a dilution.

$$
\begin{aligned}
& R E_{t}=-20.602+1.14238 *\left(\mathrm{Fe}^{2+}\right)_{o}+0.102791 *\left(\mathrm{H}_{2} \mathrm{O}_{2}\right)_{o}+0.138419 * \mathrm{COD} \\
& +5.87343 * t-0.0043153 *\left(\mathrm{Fe}^{2+}\right)_{o}{ }^{2}-0.000406362 *\left(\mathrm{Fe}^{2+}\right)_{o}\left(\mathrm{H}_{2} \mathrm{O}_{2}\right)_{o} \\
& -0.000813263 *\left(\mathrm{Fe}^{2+}\right)_{o} * C O D_{o}-0.0222401 *\left(\mathrm{Fe}^{2+}\right)_{o} * t \\
& -0.0000252268 *\left(\mathrm{H}_{2} \mathrm{O}_{2}\right)_{o}{ }^{2}-0.0000666185 *\left(\mathrm{H}_{2} \mathrm{O}_{2}\right)_{o} * \mathrm{COD} \\
& -0.00462 *\left(\mathrm{H}_{2} \mathrm{O}_{2}\right)_{o} * t-0.0000277821 * \mathrm{COD}_{o}^{2} \\
& -0.00615258 * \mathrm{COD}_{o} * t-0.0165629 * t^{2}
\end{aligned}
$$

The data in Table 2 show that the model developed describes properly the Fenton treatment. In the cases which were studied, the variation between $\mathrm{COD}_{\mathrm{d}}$ values obtained and estimated is approximately $6 \%$. These two final result, lead us to conclude that the model obtained is viable for depuration treatment of the effluent studied, by permitting us to manipulate principal variables of the process in function of the water quality represented by COD.

Further analysis of equation (9) was performed in order to establish the maximum removal efficiency to be reached by the Fenton treatment. Equation (9) was codified in the optimization software GAMS, using as lower and upper values for $\left[\mathrm{Fe}^{2+}\right]_{0}$ and $\left[\mathrm{H}_{2} \mathrm{O}_{2}\right]_{0}$ those presented as $-\alpha$ and $+\alpha$ in Table 1 . First of all, it has been found that the objective function is non-convex, since the characteristics values of its Hessian are $-0.0473,-0.0009,0.000$ and 0.0063 . Thus, as the time increases, the removal efficiency will also be increased, but the value of $\left[\mathrm{Fe}^{2+}\right]_{0}$ required will change, as can be observed in Table 3. It can also be observed that as the initial chemical oxygen demand increases, the required $\left[\mathrm{Fe}^{2+}\right]_{0}$ decreases. It is worth to notice that the required concentration of peroxide to maximize the removal efficiency is always on its minimum value. The removal process, involves chemical oxidation and coagulation, the last one because ferric hydroxocomplexes are formed. ${ }^{12-16}$ This observation is confirmed throughout different points of the process: a) the presence 
of flocs which at the end are measured as settled solids (approximately $\left.30 \mathrm{mLL}^{-1}\right), \mathrm{b}$ ) the difference between $\mathrm{COD}_{\mathrm{d}}$ and $\mathrm{COD}_{\mathrm{t}}$ in each test, having a relation $\mathrm{COD}_{\mathrm{d}} / \mathrm{COD}_{\mathrm{t}}$ between 0.20 to $0.40, \mathrm{c}$ ) the large and rapid decline concentrations of $\mathrm{Fe}^{2+}, \mathrm{Fe}_{\mathrm{t}}$ and $\mathrm{Fe}^{3+}$ indicates that iron is removed from the solution. ${ }^{17}$ In order to confirm these points, a kinetic study was conducted at $\left(\mathrm{Fe}^{2+}\right)_{0}$ of $55.8 \mathrm{mgL}^{-1},\left(\mathrm{H}_{2} \mathrm{O}_{2}\right)_{0}$ of $200 \mathrm{mgL}^{-1}, \mathrm{pH}$ of 3 and for a total of 60 minutes. The process occurred too quickly and it was divided in two parts for explaining it, procedure referred in other investigations, ${ }^{18,19}$ as is presented in Figure 2. Figure 2(a) depicts the kinetic in the first two minutes and Figure 2(B) depicts the kinetic from 2.5 to $60 \mathrm{~min}$. In both cases a kinetic model of second order was used, having high correlations, with $\mathrm{R}^{2}$ of 0.9806 and 0.9951 respectively. We experienced a relation $\mathrm{COD}_{\mathrm{d}} / \mathrm{COD}_{\mathrm{t}}$, which decreased throughout the process from 0.45 to 0.27 (Figure 3 ).
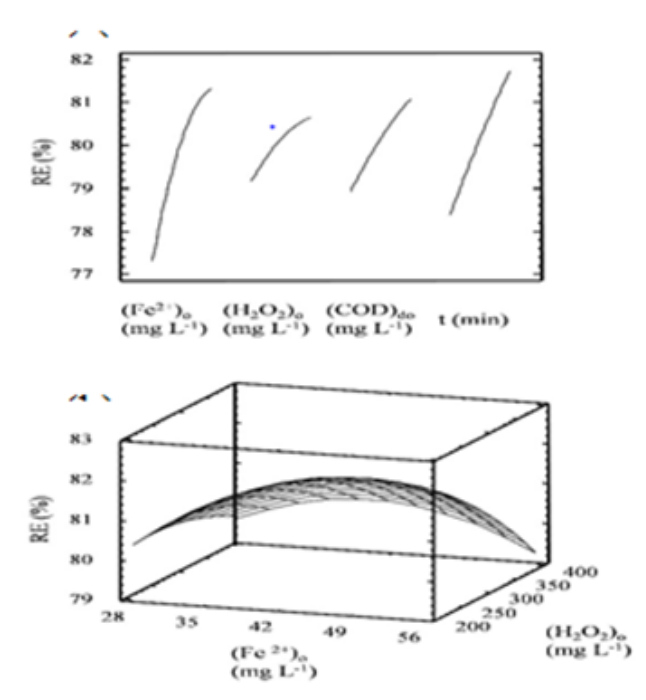

Figure IA Depicts the behavior of principal factors, showing that by increasing each one, RE increases, having different levels of influence in the following order of magnitude: $\left(\mathrm{Fe}^{2+}\right)_{0}>$ time $>\mathrm{COD}_{\mathrm{t}}>\left(\mathrm{H}_{2} \mathrm{O}_{2}\right)_{0}$.

Figure IB Depicts the response surface for the optimal removal condition of $C O D$ for one of the effluents studied $\left(C_{0}\right.$ of $\left.503 \mathrm{mgL}^{-1}\right)$ at $10 \mathrm{~min}$, corresponding to a true sample, not a dilution.

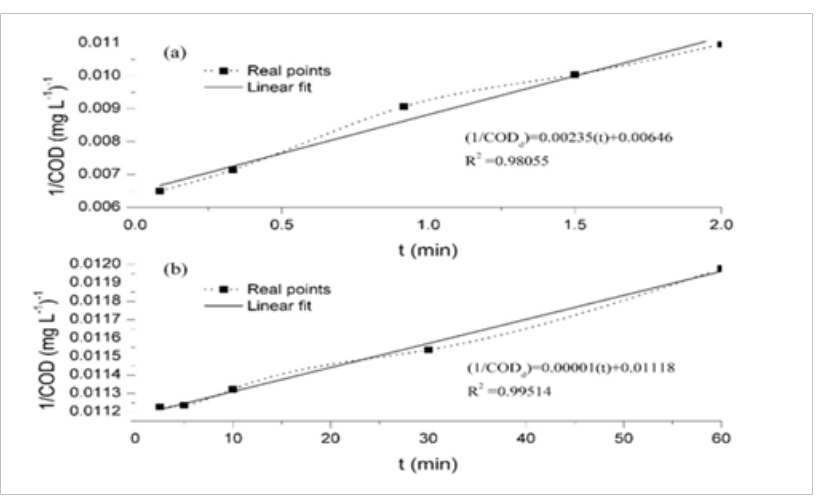

Figure 2A Depicts the kinetic in the first two minutes.

Figure 2B Depicts the kinetic from 2.5 to $60 \mathrm{~min}$. In both cases a kinetic model of second order was used, having high correlations, with R2 of 0.9806 and $0.995 \mathrm{I}$ respectively. We experienced a relation CODd/CODt, which decreased throughout the process from 0.45 to 0.27 .

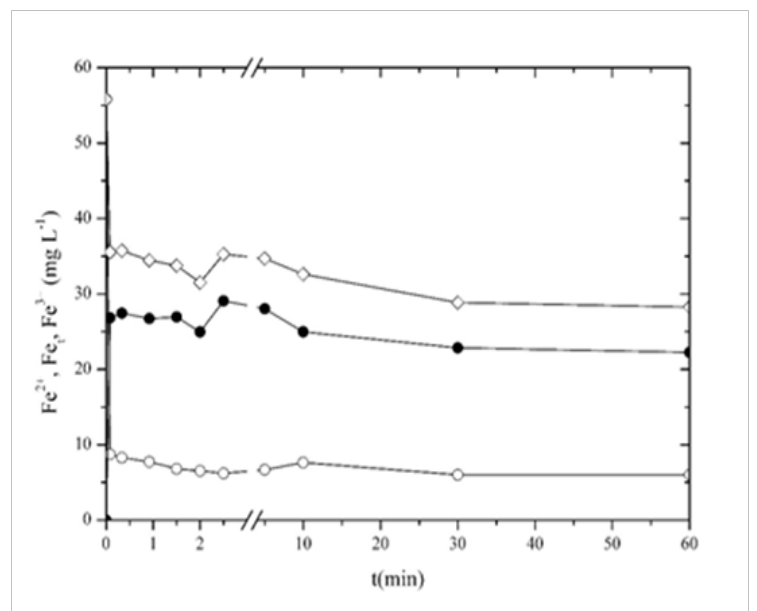

Figure 3 Depicts the behavior of the different forms of iron, showing the removal of total iron from the solution, confirming coagulation.

Table 2 Describes properly the fenton treatment

\begin{tabular}{|c|c|c|c|}
\hline \multirow[b]{2}{*}{ Type of sample } & \multirow[b]{2}{*}{$\mathrm{DQO}_{0}\left(\mathrm{mg} \mathrm{L}^{-1}\right)$} & \multicolumn{2}{|l|}{ Fenton treatment } \\
\hline & & $\begin{array}{l}\text { COD } \text { estimated } \\
\text { by model }\left(\mathrm{mg} \mathrm{L}^{-1}\right)\end{array}$ & $\begin{array}{l}\mathrm{COD}_{\mathrm{d}} \\
\text { rea } \\
(\mathrm{mg} \\
\left.\mathrm{L}^{-1}\right)\end{array}$ \\
\hline $\begin{array}{l}\text { Effluent from local } \\
\text { facility }\end{array}$ & 503 & 89.2 & 83.7 \\
\hline $\begin{array}{l}\text { Effluentfrom local } \\
\text { facility }\end{array}$ & 581 & 108.4 & 115.9 \\
\hline
\end{tabular}

Table 3 Describes properly the fenton treatment

\begin{tabular}{lllll}
$\begin{array}{l}\mathbf{C O D}_{\mathbf{0}}(\mathbf{m g} \\
\left.\mathbf{L}^{-1}\right)\end{array}$ & $\mathbf{R E}_{\mathbf{t}} \mathbf{m a x}$ & $\left(\mathrm{Fe}^{\mathbf{2 +}}\right)_{\mathbf{0}}\left(\mathbf{m g ~ L}^{-1}\right)$ & $\begin{array}{l}\left(\mathbf{H}_{\mathbf{2}} \mathbf{O}_{\mathbf{2}}\right)_{\mathbf{0}}(\mathbf{m g} \\
\left.\mathbf{L}^{-1}\right)\end{array}$ & $\mathbf{t}(\mathbf{m i n})$ \\
\hline 265.1 & 98.756 & 64.022 & 100 & 15 \\
355 & 98.473 & 42.666 & 100 & 20 \\
435.5 & 98.838 & 27.35 & 100 & 23 \\
503 & 98.465 & 13.259 & 100 & 26 \\
583.8 & 98.537 & 13 & 100 & 38 \\
\hline
\end{tabular}

\section{Conclusion}

The model developed for the depuration treatment of the effluents from the slaughterhouse is viable for use under real conditions as a method for adjusting of the process when changes the water quality. By using this model is becomes possible to acquire design and operation information, ensuring water with high and stable quality. The removal efficiencies of COD obtained greater than $85 \%$, are based on chemical oxidation and coagulation process, showing that it is viable for use in depuration of this effluent and others of similar origin.

\section{Acknowledgements}

Financial support from PRODEP-UGTO-PTC-472 and UGTO under the Project 007/2015, and 778/2016, is acknowledged. 


\section{Conflict of interest}

The author declares no conflict of interest.

\section{References}

1. Frenkel VS, Cummings GA, Maillacheruvu KY, Food-processing wastes (Review). Water Environ Res. 2016;88(10):1395-1408.

2. Oller, S Malato, JA Sánchez-Pérez. Combination of advanced oxidation processes and biological treatments for wastewater decontamination-a review. Sci Tot Environ. 2011;409(20): 4141-4166.

3. Ein-Mozaffari F, Mohajerani M, Mehrvar M. An overview of the integration of advanced oxidation technologies and other processes for water and wastewater treatment. Int J Eng. 2009;3(2):120-146.

4. Kabdaşli I, Arslan T, Arslan-Alaton I, et al. Organic matter and heavy metal removals from complexed metal plating effluent by the combined electrocoagulation/Fenton process. Water Sci Tech. 2010;61(10):26172624 .

5. EJ Ruiz, C Arias, E Brillas, et al. Mineralization of Acid Yellow 36 azo dye by electro-Fenton and solar photoelectro-Fenton processes with a borondoped diamond anode. Chemosphere. 2011;82(4):495-501.

6. Wu Y, Zhou S, Qin F, et al. Modeling the oxidation kinetics of Fenton's process on the degradation of humic acid. Journal of Hazardous Materials. 2010;179(1-3):533-539.

7. Neyens E, Baeyens J. A review of classic Fenton's peroxidation as an advanced oxidation technique. J Hazard Mat. 2003;98(1-3):33-50.

8. Liu H, Li XZ, Leng YJ, et al. Kinetic modeling of electro-Fenton reaction in aqueous solution. Water Res. 2007;41(5):1161-1167.

9. Paramo Vargas J, Chavez EI, De la Rosa C, et al. Treatment by advanced oxidation processes for an effluent of an anaerobic digester from a slaughterhouse. Sust Environ Res. 2015;25(4):195-205.
10. American Public Health Association AWWA. Water Environment Federation. Standard Methods for the examination of water and wastewater. 20th edition. Washington, USA: American public health association; 1998.

11. Peralta-Hernández JM, Meas-Vong Y, Rodríguez FJ, et al. Comparison of hydrogen peroxide-based processes for treating dye-containing wastewater: Decolorization and destruction of Orange II azo dye in dilute solution. Dyes and Pigments. 2008;76:656-662.

12. Deng Y. Physical and oxidative removal of organics during Fenton treatment of mature municipal landfill leachate. J Hazard Mat. 2007;146(12):334-40.

13. Kang YW, Hwang KY. Effects of reaction conditions on the oxidation efficiency in the Fenton process. Water Res. 2000;34(10):2786-2790.

14. Lau IWC, Peng W, Herbert HPF. Organic removal of anaerobically treated leachate by Fenton coagulation. J Environ Eng. 2001;127:666-669.

15. Paramo-Vargas J, Camargo AME, Gutierrez-Granados S, et al. Applying electro-Fenton process as an alternative to a slaughterhouse effluent treatment. J Electroanal Chem. 2015;754:80-86.

16. Zhang $\mathrm{H}, \mathrm{Wu} \mathrm{X}, \mathrm{Li} \mathrm{X}$. Oxidation and coagulation removal of COD from landfill leachate by Fered-Fenton process. Chem Eng J. 2012;210:188194.

17. J Páramo-Vargas, S Granados, MI Maldonado-Rubio, et al. PeraltaHernández. Up to $95 \%$ reduction of chemical oxygen demand of slaughterhouse effluents using Fenton and photo-Fenton oxidation. Environ Chem Lett. 2016;14:149-154.

18. Méndez-Díaz J, Sánchez-Polo M, Rivera-Utrilla J, et al. Advanced oxidation of the surfactant SDBS by means of hydroxyl and sulphate radicals. Chem Eng J. 2010;163:300-306.

19. Üstün GE, Solmaz SKA, Morsünbül T, et al. Advanced oxidation and mineralization of 3-indole butyric acid (IBA) by Fenton and Fenton-like processes. J Hazard Mat. 2010;180:508-513. 